\title{
Synthesis of potencial inhibitors of HIV-1Nef.
}

\author{
Carlos Eduardo M. Salvador, Carlos Kleber Z. Andrade* \\ Laboratório de Química Metodológica e Orgânica Sintética (LaQMOS), Instituto de Química, Universidade \\ de Brasília, C.P. 4478, 70910-970, Brasília, DF, Brasil
}

"Corresponding author.Tel.: +55 (61) 31073861; fax: +55(61) 32734149; e-mail: ckleber@unb.br

Keywords: HIV-1, Nef protein and CD4

\section{INTRODUCTION}

A decreasing of the expression of CD4 receiver in the surface of the infected cells by Nef is one of the most important events during the infection by HIV-1. The identification of Nef inhibitors is very important to the treatment of HIV infection. The development of new therapies and methods of synthesis of Nef antagonists is a new and highly specific therapeutic approach and aims at eliminating the side effects involved with the existing anti-retroviral cocktail. To achieve this goal, we propose to synthesize a series of inhibitors of degradation of CD4 by Nef beginning with molecular modeling studies of the Nef protein and its catalytic domains involved in this function. ${ }^{1}$ In this sense, compound 1 seems to be one of the most promising (Figure 1). ${ }^{2}$

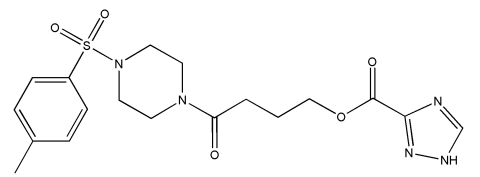

Figure 1: Structure of a potential Nef inhibitor.

\section{RESULTS AND DISCUSSION}

The first step of the synthesis of compound 1 is the sulfonation of piperazine $\mathbf{3}$ in the presence of pyridine in dichloromethane, affording compound 4 in $92 \%$ yield (Scheme 1 ).



Scheme 1: Synthesis of compound 1.

The next step involved the opening of $\mathrm{Y}$ butyrolactone by compound 4 . Among the different experimental conditions investigated, the use of $\mu \mathrm{w}$ irradiation $\left(130{ }^{\circ} \mathrm{C}, 200 \mathrm{~W}, 1 \mathrm{~h}\right)$, was the only one to furnish compound 6 (Table 1 , entry 5 ), thus demonstrating the efficiency of the microwave assisted reaction in contrast to the reactions under reflux.

Table 1. Experimental conditions for the opening of $y^{-}$ butyrolactone opening by compound 4 .

\begin{tabular}{|c|c|c|c|c|c|}
\hline Entry & $\begin{array}{c}\text { Time } \\
(\mathrm{h})\end{array}$ & $\begin{array}{c}\text { Temperature } \\
\left({ }^{\circ} \mathrm{C}\right)\end{array}$ & Solvent & $\begin{array}{c}\text { Pressure } \\
(\mathrm{atm})\end{array}$ & $\begin{array}{c}\text { Yield } \\
(\%)\end{array}$ \\
\hline 1 & 15 & Reflux & Metanol & 1 & - \\
\hline 2 & 0,25 & Reflux & $\mathrm{CH}_{2} \mathrm{Cl}_{2}$ & - & - \\
\hline 3 & 72 & 60 & $\mathrm{CHCl}_{3}$ & 120 & - \\
\hline 4 & 1 & $40 / \mu \mathrm{w}$ & $\mathrm{CH}_{2} \mathrm{Cl}_{2}$ & - & - \\
\hline 5 & 1 & $130 / \mu \mathrm{w}$ & - & - & 79 \\
\hline
\end{tabular}

In the final stage of the synthesis, compound 6 was coupled with 1,2,4-triazole-3-carboxylic acid 7 . Some coupling agents were tested, such as DCC / DMAP, EDC and PYBOP. Only the latter was able to provide compound 1 in $84 \%$ yield (Scheme 2 ). ${ }^{3}$

\section{CONCLUSION}

Compound 1, a potential inhibitor of HIV-1 Nef, was efficiently obtained from piperazine by a 3-step sequence and its pharmacological properties will be now evaluated.

\section{ACKNOWLEDGEMENTS}

IQ-UnB, CAPES/REUNI, CNPQ and FINEPCTINFRA $n^{\circ}$ 0970/01.

\section{REFERENCES}

${ }^{1}$ Arganaraz, E. R.; J. Biol. Chem. 2003, 36, 33912

${ }^{2}$ Salvador, C. E. M., Andrade, C. K. Z., Martins, J. B. L, $33^{a}$ Reunião Anual da SBQ, 2010,

${ }^{3}$ Ulrich, M. S.; Buzko, O.; Shah, K.; Shokat, M. K.; Tetrahedron 2000, 56, 9495. 